\title{
The Equation of Iconography of Cracking Bodies in Bapsi Sidhwa's Cracking India
}

\author{
Saroj GC \\ Facilitates courses in MPhil, \\ Nepal Open University, Lalitpur, Nepal
}

Lenny, a young Parsi girl coming of age at the time of Partition and independence, in Sidhwa's novel Cracking India, says "there is no space for us in Queen's Garden"1. She basically refers to the literal space - the lack of space to accommodate herself and other friends in the Garden, for it is being crowded because of increasing communal violence. However, Lenny's literality of questioning the space cannot be taken for granted. This voice of the innocent, Lenny triggers prominent thematic content in socialcultural context of Partition. If her search for space is seen in broad spectrum of Partition violence of 1947 in India, she as representative of both female figures and the neutral and the marginalized people, is seeking more significant space in context of Partition violence; it is a search for the space for female in nationalist discourse. The search, by the same token, corresponds with the objective and the rhetoric of Sidhwa- questioning the historiography of nationalist discourse. Looking from this perspective, space is not just literal one. Additionally, the "Queen's Garden" becomes metonymic manifestation of the project of empire, or cultural mission of colonization, and the subsequent consequence, nationalism.

The preliminary enthusiasm of national independence is embarked on the transaction between and among gendered female figure, the country and the violence. "In the literary imagination of India, the violence of Partition was about inscribing desire on the bodies of women in a manner that we have not yet understood. In the mythic imagination in India, victory or defeat in war was ultimately inscribed on the bodies of women" (Das 82). Thus, the female bodies in Partition exemplify the "intimate connection" of sexuality in the construction of nationalism (Das 82). The novel ingeniously uncovers the frenzied nature and inherent contradictions of the nation that attempts to justify its behaviors and conducts with ideology of emancipation. The ideology of emancipation is perpetrated on the equation of a woman's body and its violation to nationalist violation. Therefore, my discussion stages a paradox - iconizing the mother figure, and denunciation of mother figures in Cracking India. In other words, this paper argues that Sidhwa in this novel tries to question this historiography- the independence movement began by identifying nation with mythic female figure but pays no attention to the "cracking bodies". Therefore, this novel contends this masculine logic of national consciousness which strategically denies the incorporation of female existence in national historiography.

Sidhwa is trying to give a literary corrective response to the national narrative in the context of national independence by both dramatizing the predicament of women and agency to speak about the violence through female bodies. She questions the nationalism that was much built upon the iconography of female body and personality. Ironically, the site upon which the victory was rejoiced is often forgotten during the uprising of nationalist action. 
Mobilization of woman figure is a commonplace metaphor in fictional and historical narratives that portray the rise of the modern nation-state. Nationalist discourse in South Asia is no exception to this practice. In South Asian context, especially in during the period of struggle for independence, "Woman" has been used as "the alibi for colonial and nationalist interventions into the everyday lives of South Asians" (Didur 41). However, this mobilization of woman/mother figure, according to feminist critics, has less to do with the changing the actual material conditions of their lives, and more to do with patriarchal "struggles over community autonomy and the right to self-determination" (Mani 30). "Women become sites upon which various versions of scripture/tradition/law are elaborated and contested" (Mani, "Contentious" 115). Sidhwa's novel is not an exception. Depiction and mobilization of the female figures in Cracking India has given rise to the multifarious voices among the critics.

As observed by many critics, much enthusiasm of nationalism, especially in context of Indian independence, were founded on the logic that the nation resembles with the mother figure, the woman venerated in Indic civilization ${ }^{2}$. In other words, nation is an emblem of female figure, notably the mother figure. And, the colonization was an offensive intervention into a holy mother figure. Moreover, the nation was identified with the mythical heroines like Kali, Durga, and Chandi figures from Hindu mythology. Then, nation during the independence movements was sexualized and gendered $^{3}$. However, the iconography of nation as female body took ironic way in which it turned out to be too mythological that the females, who exist in the material world apart from the mythic world, were rarely mentioned in the national narrative ${ }^{4}$, here in the case of Partition violence.

Correspondingly, Rosemary George observes that Partition texts, including the novel, routinely depict women as "communal sufferers, familial victims, and second-class citizens", their pathos no longer counts seminal to nationalist action (138). Yet, this would be too limiting. The female characters in Cracking India "demonstrates not only survivorship, but also agency, using their familial and communal connections and unique perspective to affect change and bring healing" (Kleist 70). Analyzing the several situations in Cracking India, Kliest, views that Lenny, her ayah, her mother, and her Godmother are able to move beyond traditional female roles and to exercise autonomy and influence within their patriarchal society. "A radical critique of literature, feminist in its impulse" would be to see "how we [female] live, how we have been living, how we have been led to imagine ourselves [themselves] in the given situation" (Rich 350). Ambreen Hai perceives Cracking India as a piece of "narratival border feminism that undoes binary oppositions" (390). Kliest views that by utilizing a female narrator, Sidhwa presents a uniquely gendered perspective of Partition, and argues that the "novel provides a comparatively inclusive view of the diverse feminine roles during Partition, roles in which the female characters are not entirely empowered nor entirely victimized" (70). For Kleist, as Cracking India foreground the narratives of female characters, it is able to "describe, restore, and heal some of the damage done by . . . male neonationalistic discourse" (Hai 390). And, the novel is facilitating "a more nuanced understanding of the various ways women were influenced by and responded to, Partition (Kleist 70). However, women characters in the novel are predominantly victims rather than agents. 
The novel's route is filled with the narratives of "cracking bodies" of many female characters, significantly that of Ayah and Lenny, that "cracked" enough during the partition violence. Literally, the cracking of Lenny's body is biological, as she transforms from early stage of her childhood to another. However, with this Lenny's transformation, Sidhwa is hinting to the transformation that takes place at the national level, nation's soon cracking into Pakistan as soon as it has got independence from the colonization. While telling the story of partition of India through the eyes of a young Lenny, a Parsee girl from Lahore, Sidhwa also tells the deterioration that takes place in Lenny's life as her idyllic childhood is inflected by the interracial clashes of preindependence Lahore. The novel's insistent focus on body, especially the eros and sexual development, hints to two aspects: the transformation that will soon take place in the national body of India and Pakistan and the literal body of Lenny and Ayah. In the outset of novel, revelation of the fact that Lenny is diseased child and the treatment of polio foreshadows the political life of the national body.

The harmony Lenny's body feels with the relatives, including Godmother, Ayah and electric aunt, takes the path of deterioration. Lenny narrates the events of her family and native Lahore over more than a ten-year period, from before World War II to just after Indian independence and the partition (Den Geddes n. pg). The period is filled with the changes; however, the changes are negative. People around Lenny divide along racial/religious lines and eventually slaughter one another. Sidhwa shows us history in miniature, making it far more vivid than mere statistics about the numbers slaughtered during the tragic events of 1947-48. As her body changes does her conscience. And she "become[s] aware of religious differences" (101). Her narrative of herself and what is happening around her, and how people's desires and discontents "mediate, challenge, resist, or transform discourses in the process of defining their identities" (Canning 377).

The changes that take place in the body of Lenny are described in sexual metaphors as she observes Ayah's body: "The covetous glances Ayah draws educate me. Up and down, they look at her. Stub-handed twisted beggars and dusty old beggars on crutches drop their pose and stare her with hard, alert eyes. Holy men, masked in piety, shove aside their pretenses to ogle her with lust." (12). Education Lenny gets is sexual. She can observe the sexual appeal the eighteen years old girl, Ayah embraces. Lenny observes "she has a rolling bouncy walk that agitates the globules of her buttocks under her cheap colorful saris and the half spheres beneath her short sari-blouses" (13). More significantly, she notices that "the Englishmen no doubt had noticed" her blooming body (13). Rhetoric behind the use of such metaphors, Didur describes,

Where women like Ayah or Lenny question the interpretation of their identities by patriarchal community and state interests, they perform an act of resistance that destabilizes the dominant order. Cracking India figures Lenny as conscious of Ayah's strategic use of her multiple subjectpositions as a means to subvert the discourses that inscribe her body in multiple and contingent ways. (50) 
The multiple subject-position of Ayah's body is a power tool to redefine patriarchally redefined agency of female body. Ayah speaks the language of body; her body speaks sharper than her actions and words. Ayah "write[s] [her]self, makes her body heard" (Cixous 223). She "invent[s] the impregnable language that will wreck partitions, classes and rhetorics, regulations and codes" (Cixous 880).

Sidhwa's intervention into nationalist discourse of Independence gets more nourishment when she shows that Ayah's body, which signifies nation India before its partition into Pakistan, was not the object of gaze not only of Englishmen but more significantly by the people around her. Even if the religious differences keep on widening and the humanity has shrunk to a narrow definition: "one day everybody is themselves- and the next day they are Hindu, Muslim, Sikh, Christian," she still retains her admirers intact (101). As observed by Lenny, only the group around Ayah remains unchanged. Hindu, Muslim, Sikh and Parsee are always unified around her. Therefore, Ayah has already always been identified as nation India; she is endowed with the metaphor of unbroken- not cracked- India. Regardless of her Hindu origin, as she comes from West Punjab, galvanizes Hindu, Muslim, Sikh, Parsee admirers. Similarly, whatever the religious or ethnic origins, her admirers go all out to meet Ayah's body. Hence, she "is no long just my [Lenny's] all-encompassing Ayah - She is also a token, a larger symbol, the metaphor of nation that accommodates so far possible all the people regardless of their religious origin, ethnic orientation, and class consciousness.

Ironically, Ayah by now metaphorized as integrated nation India, begins to crumble as the religious differences widen and social upheavals become starker, partition becomes inevitable. "Ayah becomes the site upon which the violence inherent in nationalist discourse is emulated. Abducted during the partition atrocities by some of the very men who earlier wooed her with word", Ayah ultimately loses her solidified existence as iconography of nation (Sachdeva Mann 74). As he loses her consolidated existence, he loses her voice too. Lenny observes the loss of voice:

They drag Ayah out. They drag her by her arms stretched taut, and her bare feet

- that want to move backwards - are forced forward instead. Her lips are drawn away from her teeth, and the resisting curve of her throat opens her mouth like the dead child's screamless mouth." (194-95)

Sidhwa sides with the loss of Aya's voice during the abduction. The loss of voice is more than literal. Ayah, though in a broader spectrum represents the integrated thus disintegrated nation in partition context of India and Pakistan, also symbolizes the voice of the marginal and subaltern. Ayah is a Hindu, living a small village, Lahore, with her tiny world. She questions this systematic and pervasive disregard for female consent that leads logically to the abductions and disappearance of females during the Partition violence. Therefore, by foregrounding the loss of voice both Ayah as subaltern and as subaltern woman, Sidhwa intends to trigger into national narrative which so far occluded this voice. This loss of voice in feminist discourse corresponds to loss of agency and citizenship. This loss of agency is double-edge: she loses her agency or presence as female and also as a representative of Parsi community. "The tension between the material and imaginary events inscribed in Sidhwa's narrative suggests how the 
discourses of gender and nation overlap, converge, and become increasingly restrictive of women's agency as the country faces independence" (Didur 44). Before Partition, Ayah sincerely expresses sexuality with admirers coming from diverse social and cultural backgrounds. She expresses her sexuality in multiple and fluid fashion. However, after Partition, her sexuality is cracked; it is exploited, tarnished, used and bargained.

The national narratives of sub-continental society regarding the communal violence occluded some aspects of its history. Therefore, Ayah's story is not the story of a single person; it is paradigmatic: like her, thousands of women were abducted and/or raped by the men of opposite community during months of before and after Partition. Therefore, scholarship on the novel has repeatedly "focused on the figure of the Ayah, analyzing the ways she inhabits the subaltern subject position and how her abduction and recovery participate in the contested ideologies of Partition history" (Mitra 4).

Similarly, she questions the ideologies of Partition history by parodying the national heroes, or rather reversing the roles recorded in the Partition history. Sidwa's parody of national heroes like Jawaharlal Nehru, Vallabhbhai Patel, Mahatma Gandhi, Mohammed Ali Jinnah and other Hindu and National heroes interrogates the objectivity of nationalist discourse as exemplified in partition. Moreover, the history that novelist unravels take feminine direction in which Gandhi is given feminine attributes. Though the presumed historical information that the young girl gives can be questioned, Sidwa casts Gandhi's disposition with a shrewd humor, whatever her political ends, Gandhi is feminized, is delineated in feminine metaphors: "he is knitting. Sitting cross-legged on the marble floor of a palatial veranda, he is surrounded by women. He is small, dark shriveled, old. He looks like just Hari, our gardener, except he has disgruntled, disgusted and irritable look, and no one'd dare pull of his dhoti" (94). Later, more fully, Lenny "comprehend[s] the nature of the ice lurking deep beneath the hypnotic and dynamic femininity of Gandhi's non-violent exterior" (96). Similarly, Nehru is also attributed with feminine metaphors: he is like a female promising, pinkish, smiling and so on. In Lenny's perception, Nehru is 'suave Cambridge-polished, he carries about him an aura of power and presence that flatters anyone he compliments tenfold. He doles out promises, smiles, kisses-on-cheeks [...]. He is handsome: he cheeks glow pink" (170). What can be construed out of all this feminization of historical details is that Sidwa wants to revise the history national narrative of partition violence with revisionist impulse.

Sidwa furthers the act of revision of nationalist action when she attempts to reverse the historical roles allocated to the national heroes like Nehru, Jinnah and Patel. Sidwa's rendition of these national heroes is pregnant with irony: "within three months seven million Muslims and five million Hindu and Sikhs are uprooted in the largest and most terrible exchange of population known to history" (169). Later, through the observation of Lenny, Sidwa passes a crucial critical commentary over this whole phenomenon of violence: "Now that its objective to divide India is achieved, the British favor Nehru over Jinnah" (170). Whatever the historical accuracy might be, if Nehru was under the patronage of British Empire or not. Sidwa accounts for the loss, the loss in which the greater portion is shared by the marginal innocent people. Similarly, Jinnah 
in the novel does not turn out to be Judas, who in fact, in the national narrative is considered as complicit for this partition violence". Rather, he is "sallow, whip-thin, sharp-tongued and uncompromising" (170). The putative observation Lenny of historical and political information can precisely be questioned as she is a child.

This lack Sidwa might be using to question the objectivity that history of partition history, lack symbolized its failure to incorporate the female's fate and suffering in its historical narrative thus narratives of partition violence are not objective as such. Lack of objectivity in Lenny's narrative corresponds with the lack of objectivity in partition in which it failed to truly account for the voice of the marginalized. "A member of a minority by population the Parsi numbered only about three hundred in Lahore at the partition time. Lenny further refracts the historiography of Indian nationalism through a child's perspective, thereby investing her account with objectivity rare in other fictions of period" (Suchdeva 73). Moreover, by giving a narrative voice to the innocent child, the novelist aims to foreground the voice of many innocent people whose voice passed away unheard. Therefore, self-reflexively Sidwa sees to be giving a literary corrective response to national narrative which elided the experience of suffering by women and other neutral groups inflicted upon then national movement.

This excavation of suppression of femininity in historical narrative gets more substantiation as Lenny is interested in Jinnah's wife. She recounts Jinnah's wife as "defying

and braving the disapproval of their rigid community and excommunicated, she marries a Muslim lawyer, twenty years older than her" (170). When Lenny asks with her mother where she is, mother's eyes are unresponsive, however, mother says she died of heart broken. However, Lenny is not satisfied to her mother's answer as she contemplates: "Her daring to no account [;] her defiance humbled [;] her energy extinguished [;] only her image in the photograph and her innocence - remain intact" (179-71). While attempting to delve into the history of Jinnah's wife, she gets chance to reflect over how Jinnah is rendered in books and films: "The Ambassador of Hindu-Muslim Unity" is caricatured and portrayed as monster" (171). Similarly, women of Lahore try to repair the damage done to the community by the men. Similarly, unlike in many other national narratives, Sidhwa accounts for the contribution of women to save the cracking bodies during the partition violence. Lenny's mother leads other women in smuggling gasoline in order to raise money to send defamed women back to their families. Lenny's Godmother is revealed to be a matriarch of considerable powers and influence. She is able to locate the violated Ayah, and rescue her from Ice-Candy Man's clutches, and send her back to her family in India.

However, the subsequent excerpt Sidhwa draw a character description of Jinnah from Naidu Sarojini, a poet who was closer to him was infatuated to his personality, questions the villainous image of Jinnah presented during freedom struggle and after independence and shuns away the hostile reviews of Jinnah. By displaying anguish at the biased work of the British and Indian scholars, she assesses Jinnah's personality "with the impartiality as well as personal proclivity for the man who wrought out Pakistan with foresight and dedication" (Sarkar 82). Such acclamation of Sidhwa of Jinnah "recreates a grand image of the man who condemned by Gandhian polity for the 
sake of political appropriation" (Sarkar 83). Therefore, Sidhwa, through literary history, aims to correct the historical distortion and accounted for Jinnah.

Finally, to return to Ayah, Ayah now as a cumulative reference to the females who suffered during the violence, disappears by the end of novel. Disappearance of Ayah's body posits one of troubling questions to the nationalist discourse. However, Sidwa seems to be giving communal reason for Ayah's abduction. Here, Ice Candy Man exposes his strong sense of religious vengeance and his hatred for Hindus. He explains the Muslim tenants, including him, were humiliated to Singh's womenfolk and his strong desire to kill some of Hindus in order to recover the mutilation of Muslims on the train from Gurdaspur: I want to kill someone for each of the breasts they cut off the Muslim women ... The penises!" (166). The roles allocated to Godmother and Lenny's mother in rehabilitating are fortifying. They, thus, healing powers against the forces of violence. Therefore, by blending gender and the politics, Sidwa makes the issue of females a pivot around which the novel revolves. The central issue in the novel, thus, makes a space for Sidhwa to complain against nationalist discourse.

Sidwa complains that the national narrative regarding nation conscious suffers from elision of female figure, the foundation upon which the discourse of nationalism was based, from national memory, female domesticity, decries of woman and their bruised bodies. Thus, Sidwa attempts to revive the nationalist discourse which both was founded by iconizing the female figures and also forgot the female figures through the literary rendition. She, much in similar line of Adrienne Rich, tries to supply the historical lapses the nationalist discourse suffered. Rich regarding the revisionist historiography argues: "This is why the effort to speak honestly is so important. Lies are usually attempts to make everything simpler - for the liar - than it really is, or ought to be "(188). Therefore, the novelist one of the major takes is the contribution of female during the nationalist movement(s) have not got sufficient articulation Queen's Garden, subsequently, nationalist discourse. Females conformed only to the mythic identity but they were excluded from the nationalist discourse. Then if post-coloniality is a condition, then, it obscures the women plight and experiences; it is obfuscating and unstable with respect to women (McCllintock 91-2). The intersection of nationalism and sexuality that began with the nationalist movement in India on the assumption that colonization has destroyed native masculinity and traversed into the nation as desiring but chaste faces a problem.

\section{Works Cited}

Anthias, Floya. Woman, Nation, Stale. Houndmills: MacMillan, 1989.

Butalia, Urvashi. "Community, State and Gender: On Women's Agency during Partition." Economic and Political Weekly 24 Apr. 1993, p. 12-24.

Canning, Kathleen. "Feminist History after the Linguistic Turn: Historicizing Discourse and Experience." Signs vol.19 no. 2,1994, p. 368-404. 
Cixous, Hélène. "Sorties: Out and Out: Attacks/Ways Out/Forays." Belsey, Catherine/Moore, Jane (Hg.): The Feminist reader: essays in gender and the politics of literary criticism, New York (1989).

Cixous, Helene. "The Laugh of the Medusa." Trans. K. Cohen and P. Cohen. Signs vol. 1 no.

4 (Summer 1976), p. 880-886.

Cullingford, Elizabeth Butler. "Thinking of Her as Ireland': Yeats, Pearse and Heaney." Textual Practice vol. 4 no.1,1990, p. 1-21.

Das, Veena. "Language and Body: Transactions in the Construction of Pain." Social Suffering. Eds. Arthur Kleinman, Veena Das and Margaret Lock. Berkeley: U of Califomia P, 1997.67-98.

Didur, Jill. "Cracking the nation: gender, minorities, and agency in Bapsi Sidhwa's" Cracking India." ARIEL: A Review of International English Literature vol. 29 no. 3, 1998, p. 43-64.

Geddes, Dan, "Review: Cracking India." The Satirist: America's most Critical Journal. $\begin{array}{lllll}\text { March } & 2000 . & \text { Web } & 20 & \text { July }\end{array}$ <http://www/thesatirist.com/books/CrackingIndia.html>

George, Rosemary Marangoly. "(Extra)ordinary Violence: National Literatures, Diasporic Aesthetics, and the Politics of Gender in South Asian Partition Fiction." Signs: Journal of Women in Culture and Society, vol. 33, no. 1, 2007, pp. 135-158., doi:10.1086/518371.

Hai, Ambreen. "Border Work, Border Trouble: Postcolonial Feminism and the Ayah in Bapsi Sidhwa's Cracking India." MFS Modern Fiction Studies, vol. 46 no. 2, 2000, p. 379-426. Project MUSE, doi:10.1353/mfs.2000.0028.

Kleist, Jacquelynn M. "More than Victims: Versions of Feminine Power in Bapsi Sidhwa's Cracking India.” A Journal of Pakistan Studies vol. 3 no. 2 ,2011, p. 69-81.

Mani, Lata. "Multiple Mediations: Feminist Scholarship in the Age of Multinational Reception." Feminist Review vol. 3 no. 5, 199, p. 24-41.

Mani, Lata. "Contentious Traditions." Recasting Women: Essays in Colonial History. Ed. Kumkum Sangari and Sudesh Vaid. New Delhi: Kali for Women Press, 1989, p. 88-126.

McClintock, Anne. "The Angel of Progress: Pitfalls of the Term "Post-Colonialism"." Social Text vol. 31 no. 32, 1992, p. 84-98.

Mitra, Madhuparna. "Contextualizing Ayah's Abduction: Patterns of Violence against Women in Sidhwa's Cracking India." ARIEL: A Review of International English Literature vol. 39 no.3, 2008, p. 23-58.

Rich, Adrienne. "When we dead awaken: Writing as re-vision." College English. vol. 34. no.

1, 1972, p. 18-30. 
Sachdeva, Harveen Mann. "Cracking India: Minority Women writers and the Contentious Margins of Indian Nationalist Discourse." The journal of Commonwealth Literature vol. 29, 1994, p. 71-94.

Nimsarkar, P. D. "Dimensionality of History and Politics in Bapsi Sidhwa's Ice-CandyMan." Contemporary Fiction: An Anthology of Female Writers, 2008, p. 78-90.

Sidhwa, Bapsi. Cracking India. Minnesota: Milkweek Editions, 1991.

Spivak, Gayatri Chakravorty. "Can the Subaltern Speak?" Marxism and the Interpretation of Culture. Ed. Gary Nelson and Lawrence Grossberg. Illinois: U of Illinois P, 1994, p. 271-313. 